\title{
Pronunciamiento de la Academia de Medicina del Instituto de Chile sobre la situación de virus ebola en Chile y el mundo
}

\author{
Statement of the Chilean Academy of Medicine on ebola virus situation \\ in Chile and the world
}

La Academia de Medicina tiene como propósito el "contribuir al progreso del conocimiento médico en todos sus aspectos, aspirando a ser la conciencia reflexiva de la medicina chilena". La Academia ha seguido, al igual que diferentes actores médicos y no médicos de Chile y el mundo, la situación del virus Ebola constatando la situación de "alarma pública" generada. En consecuencia, la Academia ha considerado oportuno el contribuir con un pronunciamiento reflexivo sobre la situación de virus Ebola en Chile y el mundo.

La Academia considera que la situación derivada de la epidemia actual por virus Ebola, evidenciada a partir del 25 de Marzo 2014 a la fecha, debe y deberá seguir siendo motivo de preocupación para la comunidad internacional toda, incluyendo la chilena, por varios motivos:

- Corresponde a una patología de gran facilidad de diseminación y alta letalidad, de carácter devastador, que causa esta infección en algunas de las zonas más empobrecidas de África. A pesar de conocerse la infección por este virus desde el año 1976, los esfuerzos por estudiarlo en mayor profundidad y avanzar en posibles tratamientos así como estrategias de control y prevención, sólo se han acelerado con la reciente epidemia a la luz de su posible extensión fuera de las zonas tradicionalmente epidémica, de lo cual se ha sabido de casos anecdóticos en España y Estados Unidos.

- La expansión de esta epidemia fuera de su lugar de origen, si bien ha sido muy limitada, se puede incrementar dado el importante aumento de los viajes intercontinentales especialmente por vía aérea. Esta movilidad creciente obliga a todos los países, incluyendo Chile, a estar adecuadamente informado y preparado para afrontar en el presente y futuro ésta y otras epidemias que puedan nacer en lugares aparentemente remotos.

- La experiencia de países cercanos a la zona epidémica demuestra que con medidas sani- tarias estrictas, el brote puede ser apropiadamente controlado. Los resultados que muestra Nigeria, declarada recientemente como país libre de Ebola, son esclarecedores y muestran al mundo que la comunión de esfuerzos puede derrotar esta epidemia.

- Ante la inexistencia de medidas terapéuticas o de inmunización demostradas, tanto en seguridad y eficacia, surge la posibilidad de aplicar antivirales, anticuerpos, plasma inmune o vacunas como medidas de urgencia aunque no hayan sido completamente estudiados. Si bien lo anterior se ha considerado éticamente justificado para una epidemia de tan alta mortalidad y rápida expansión, el uso de estas intervenciones constituye un desafío para combinar su uso compasivo y solidario, junto a una investigación seria que genere conocimiento útil para establecer tratamientos y vacunas eficaces y seguros.

Sin perjuicio de lo anterior, es importante dimensionar adecuadamente la presente epidemia a la luz del conocimiento médico actualmente disponible, identificando las áreas aún inciertas para mantener a la población adecuadamente informada y adoptar medidas proporcionales al riesgo existente. En relación a esto la Academia considera que:

- El mecanismo de transmisión de virus Ebola está bien estudiado, siendo este fundamentalmente por contacto directo con una persona enferma o fallecida y/o sus fluidos corporales, sin evidencia objetiva de transmisión por vía aérea. Si bien los estudios son pocos, existe consenso en que a mayor severidad de la enfermedad, mayor riesgo de transmitir el virus. Las personas en mayor riesgo de contagiarse son aquellos con mayor tiempo de contacto con personas gravemente enfermas, lo cual incluye al personal de salud y a los cuidadores familiares.

- La mínima o nula transmisión a partir de per- 
sonas contagiadas antes de presentar signos de enfermedad hace que la probabilidad de contagio casual en un avión sea mínima por lo que no se debe sobre reaccionar ante la presencia de personas asintomáticas proveniente de zonas afectadas. Al mismo tiempo, la posibilidad de personas provenientes de zonas vecinas no epidémicas (países vecinos o distantes de África) de estar contagiadas es prácticamente inexistente por lo que adoptar medidas de restricción o registro a personas que no provengan de la zona epidémica es una sobre reacción inapropiada que debe ser evitada. No obstante, hay que vigilar atentamente los cambios epidemiológicos e informar oportunamente a la comunidad.

- La probabilidad de que el virus Ebola llegue al país es, a la fecha, muy baja porque requiere que una persona infectada proveniente de uno de los actuales países epidémicos (Liberia, Sierra Leona, Guinea, República Democrática del Congo) arribe al país dentro de los 21 días desde su contagio. La transmisión del virus requiere que la persona contagiada enferme y entre en contacto con personas sanas, lo cual puede ocurrir en diferentes escenarios incluidos centros de salud. El adecuado aislamiento del enfermo minimiza el riesgo, conjuntamente con la vigilancia de sus contactos.

- Las medidas implementadas y por implementar en Chile en acuerdo con protocolos internacionales son necesarias, especialmente para prevenir el posible contagio al personal de salud, como se ha evidenciado a la fecha en Estados Unidos y España. El contagio, se estima que fue secundario a fallas en las muy estrictas medidas de protección personal, que derivaron en contacto de la piel o mucosa del personal con piel o fluidos de personas gravemente enfermas. No se conoce a la fecha con exactitud cuál es la magnitud de contacto requerida para infectarse ni en qué momento exacto la persona con síntomas puede transmitir la infección. Las medidas de protección son complejas, requieren de equipos de protección personal especiales junto con alta capacitación y entrenamiento del personal de salud, con supervisión.

La población debe estar adecuadamente informada para que en conjunto la sociedad reaccione y se prepare de la mejor manera ante ésta y futuras epidemias. El Ministerio de Salud debe liderar centralizadamente los esfuerzos para el control de una eventual presencia de casos en el país, dando directrices claras de los flujos de atención, garantizando máxima protección para el personal de salud y su capacitación continua, tanto a nivel del sector público como privado.

Asimismo, se debe garantizar el manejo técnicamente adecuado, no discriminatorio y digno de las personas infectadas.

Los medios de comunicación deben trabajar junto a las autoridades de salud para entregar información fidedigna, objetiva, clara y oportuna, evitar la sobre reacción y la información parcial o tergiversada.

En las últimas dos décadas Chile ha reaccionado bien para enfrentar amenazas epidémicas globales. Los aciertos y desaciertos en la preparación para cada una de estas situaciones debieran servir de base para que como país, afrontemos cada vez de mejor manera una nueva amenaza. Las autoridades de salud pueden contar en todo momento, con la ayuda técnica que requieran de parte de la Academia Chilena de Medicina para este propósito.

Santiago de Chile, 24 de Octubre de 2014 